\title{
THE OSTRAKON REVALIENSE: A REVISED TEXT
}

\author{
Klaas A. Worp
}

\begin{abstract}
This paper contains a new edition of the ostrakon Revaliense, which was first published by Konstantin Vilhelmson in 1926 and subsequently in SB IV.7274.
\end{abstract}

An exceptionally lucky coincidence, i.e. a question raised in November 2009 by Dr. Ivo Volt (Department of Classics, University of Tartu, Estonia) on the PAPY-list ${ }^{1}$ provided me with an opportunity to obtain - through his kind services - from $\mathrm{Mr}$. Tõnis Liibek M.A., curator of the Estonian History Museum in Tallinn, digital color photos of a Greek ostrakon first published almost 85 years ago by Konstantin Harald Vilhelmson. ${ }^{2}$ Vilhelmson's article "De ostraco quod Revaliae in Museo Provinciali servatur" appeared in the Acta et Commentationes Universitatis Tartuensis (Dorpatensis), Series B: Humaniora, vol. IX.6 (1926), p. 3-6, with a black and white photo of the ostrakon on p. 4.

This first edition is not easily available, ${ }^{3}$ but the Greek text of the ostrakon was subsequently reprinted by F. Bilabel in Sammelbuch IV (1931) \# 7274. Unfortunately, in the process of copying the text of the ed. princ. Bilabel committed a small error, i.e.

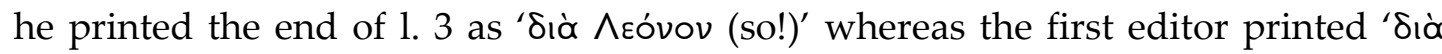
^éóvou (sic)'.

In his first edition Vilhelmson states that the ostrakon was found in 1891 under a stone on Elephantine island by Peter Zoege von Manteuffel ${ }^{4}$ and that it was donated to the Provincial Museum of Reval (= Tallinn) in 1907. Surviving the vicissitudes of the World War II and various occupations of Estonia, the ostrakon is now located in the Estonian History Museum in Tallinn ${ }^{5}$ where it has the inventory number TAAM$9494 \mathrm{~K} 538$.

Below, I present (A) Vilhelmson's text as stored in the Papyrological Navigator / Duke Data Base of Documentary Papyri, ${ }^{6}$ followed by (B) my own transcript of the ostrakon, made on the basis of the digital photos for which I owe many thanks to Mr Liibek

\footnotetext{
${ }^{1}$ A discussion list for papyrologists, see the web site: http://adam.igl.ku.dk/ bulow/papy-l.html.

${ }^{2}$ For a portrait and a short biography (in Estonian) of this scholar, see the web site of the Department of Classics of the University of Tartu: http://www.fl.ut.ee/konstantin.vilhelmson.

${ }^{3}$ I am most grateful to Dr. Volt for providing me with a copy. The scanned edition is now also available on the website mentioned in note 2 .

${ }^{4} \mathrm{P}$. Zoege von Manteuffel belonged to an ancient German noble family that was prominent in the Baltic region. The man himself was a Baltic German author who lived between 1866-1947. For a characterization (in German) of his work ("Russophobie", "Anti-Slavismus"), see the web site: http://www.carlschirren-gesellschaft.de/JO-Garleff-DB-Autoren.htm.

${ }^{5}$ For background information on the Estonian History Museum, see http://www.eam.ee/ (also available in English).

${ }^{6}$ For this tool (indispensable for papyrologists), see the web site: http://www.papyri.info.
} 
and the Estonian History Museum. Moreover, I am grateful to Dieter Hagedorn (Cologne/Heidelberg) for kindly discussing some palaeographical problems in the text by e-mail. Even so, only the present author is responsible for the new transcript of this interesting text.

(A)

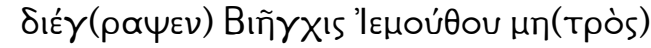

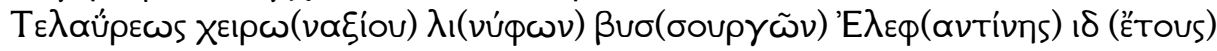

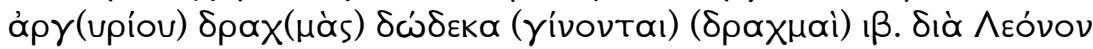

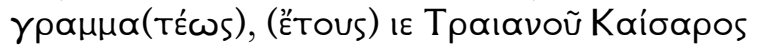

5 Toũ kupíou $\Phi \propto \tilde{\omega}(\phi ı)$ ka.

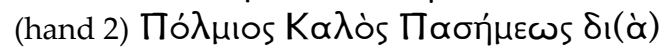

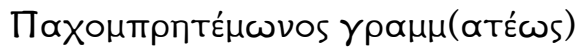

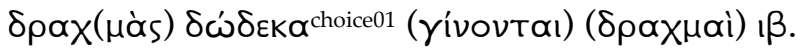

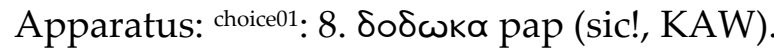

(B): New transcript of the Tallinn ostrakon:

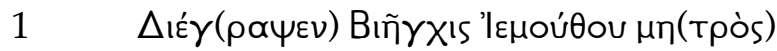

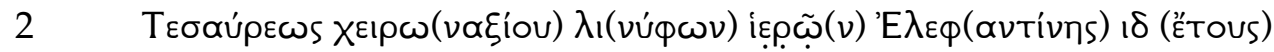

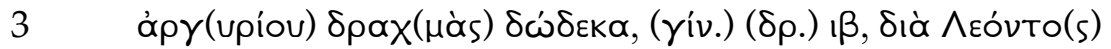

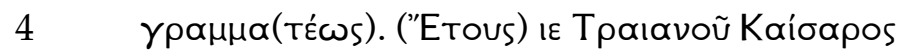

5 Toũ kupíou $\Phi \propto \tilde{\omega}(\phi ı) k \bar{\alpha}$.

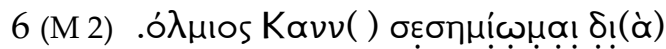

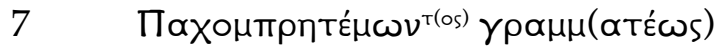

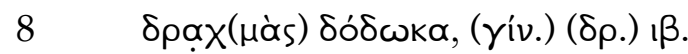

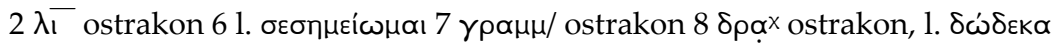

Translation:

"Has paid Bienchis, son of Iemouthes and mother / Tesauris, for cheironaxion due by weavers of the temples of Elephantine for the 14th year / twelve silver drachmas, in total 12 dr., through Leon, / scribe. In the 15th year of Trajan Caesar / the lord, on Phaophi 21th.

(M 2) I, -olmius son of Kann( ), have signed through / Pachompretemon (?), scribe (for) / twelve drachmas, in total $12 \mathrm{dr} . "$

The date of the text is 19.x.111 CE. Lines 1-5 contain a tax receipt for a payment made by Bienchis, son of Iemouthes and mother Tesauris, for cheironaxion due by weavers of the temples of Elephantine for the 14th year (of the emperor Trajan, i.e. 111/2 CE); the amount paid is 12 drachmas and the receipt was recorded by a scribe Leon in the 15th year of the emperor Trajan on Phaophi 21. It is to be expected that lines 6-8, again mentioning a payment of 12 drachmas, concern the same payment 
as recorded in lines 1-5. From this it follows that at the start of line 6 one expects the name of the tax collector who signs the receipt through a scribe Pachompretemon (?). However: no praktōr, epiterētēs or misthōtēs is already known from the Syene/Elephantine area for the years 110-112 CE and the collector's name itself is problematical, cf. line $6 n$.

\section{Notes:}

1. In itself, the name Bienchis is popular enough in the Syene / Elephantine area, but a Bienchis son of Iemouthes is nowhere else recorded. The name Iemouthes is relatively rare (there only 6 attestations in the $D D B D P$, all except this one in texts from the Arsinoite nome).

2. Despite the comments on the mother's name made by the ed. princ. ("[Telayris] adhuc inauditum --. Tesayris et Teseyris quidem, per $\sigma$ scripta, haud raro occurrunt neque tamen dubitari potest, quin hoc loco nomen per $\lambda$ scriptum exstet, longe enim alio ductu ac $\lambda$ in ostraco $\sigma$ exaratur"), I am certain that

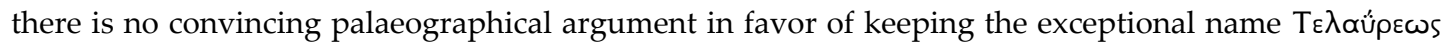
(gen.); the reading of a $-\sigma$ - instead of a $-\lambda$ - is absolutely acceptable, hence we should read, after all, the

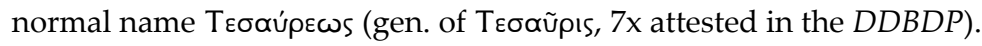

Actually, as the dots indicate, my reading iє̣p $\tilde{\omega}(v)$ is all but secure. Only so much is certain here that for palaeographical reasons the reading of the ed. princ., Buo(ooupy $\tilde{\omega} v)$ (= 'producers of fine linen'), is definitely impossible; unfortunately, there is no parallel tax receipt from the Syene / Elephantine region that offers an immediately convincing alternative (for such receipts mentioning weavers and sellers of linen, cf. O.Wilcken 45, 47, 62, 65, 73, 74, 97; O.Leid. 179 [= O.Wilcken 23]; P.Bingen 85; for other texts from the same region dealing with linen in general, cf. O.Eleph. DAIK 116; SB I 4364, V 7575 and 7579 [all texts are from the late 1st and early 2nd century CE]). In favor of the reading iє̣. $\tilde{\omega}(v)$ it may be argued that (a) our present knowledge about textile production in Egypt does not form an argument against this reading (throughout the country it is found prominently in local temples, see E. Wipszycka, L'industrie textile dans l'Egypte romaine. Wroctaw etc, 1965), while (b) the word combination $X^{\prime}(\rho \omega v \alpha-$

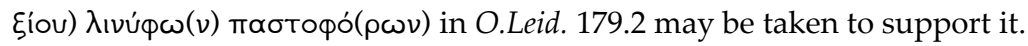

3. For the scribe Leo, cf. O.Wilcken 42 (110/1 or 111/2 CE; tax receipt issued by a certain Pompeius Valens represented by N.N.), SB I 4352 (111 CE; issued by N.N.) and O.Bodl. II 454 (112 CE; no issuer mentioned).

6. Reading here the first name as $\Pi<\tau>0 \lambda<\varepsilon / 0>\mu$ aĩos looks unlikely. I am not certain that the first letter is indeed a $\Pi$, and the cluster of spelling errors in only one form seems to make the reading of this common name here excessively dubious.

The abbreviation $\operatorname{Kavv}($ ) can be taken as the beginning of a personal name like, e.g., Kavvãs, Kavví $\omega v$, or Kavveĩs. For the form of the second -v-, cf. the same letter in Tpaı

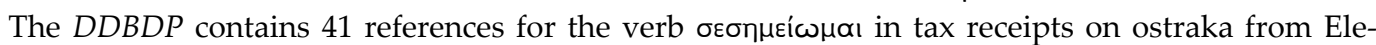
phantine.

$\Delta_{!}\left((\grave{\alpha})\right.$ is needed because of the expected formula ('Tax collector $X$, represented by scribe $\left.Y^{\prime}\right)$, but one could also read here a supralinear tau, attributable to a form $\gamma \rho \alpha \mu \mu(\alpha) \tau(\varepsilon \dot{\varepsilon} \omega)$ in 1. 7.

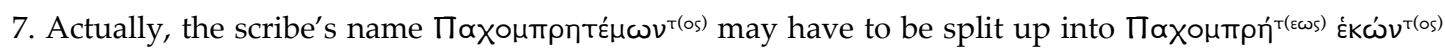

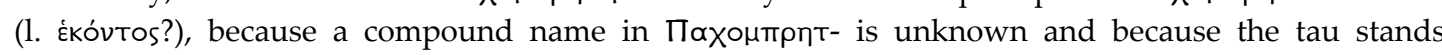
marginally higher than the other letters on this line. I cannot convince myself that a personal name in

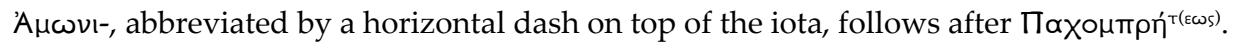

Klaas A. Worp

Papyrological Institute, University of Leiden

Witte Singel 27, NL-2311 BG Leiden, The Netherlands

E-mail:kaworp@zonnet.nl 
Appendix. Digital photos of the ostrakon Revaliense (courtesy of the Estonian History Museum, Tallinn).
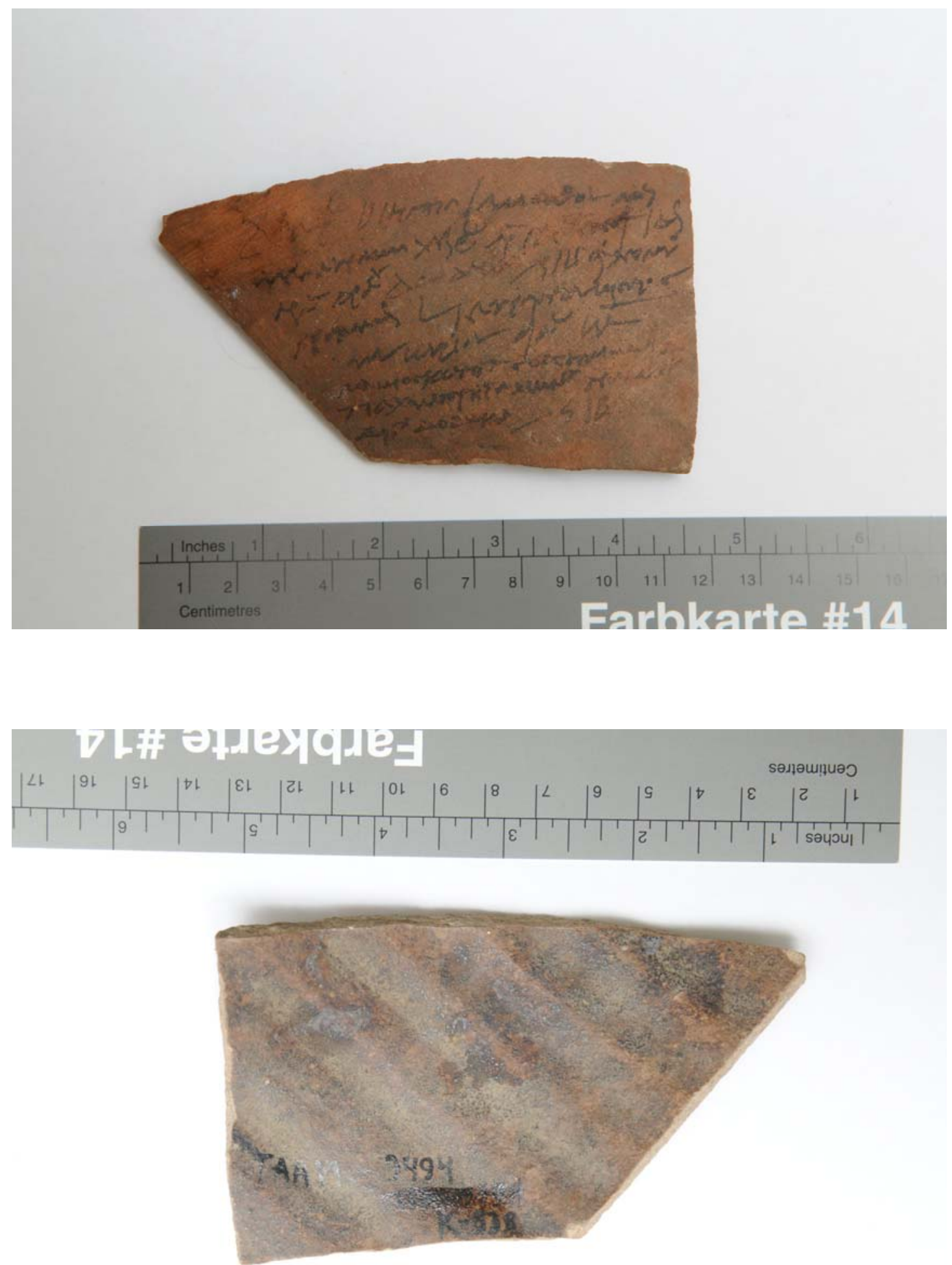